\title{
Comparative Evaluation of Bioethanol Production from Pineapple (Ananas comosus) and Cassava (Manihot esculenta) Waste from Warri
}

\author{
E.A. Fadairo $^{1 *}$ and M. I. Otite-Douglas ${ }^{1}$ \\ ${ }^{1}$ Science Laboratory Technology Department Petroleum Training Institute, Effurun, Nigeria. \\ *Corresponding Author: fadairo e@ @pti.edu.ng; ekakpan10@gmail.com, +2348033058079 \\ Received 08 May 2020; accepted 19 May 2020, published online 20 July 2020
}

\begin{abstract}
Fossil fuel is known to increase greenhouse gas emission which has resulted in serious environmental consequences. This study was designed to determine bioethanol production from pineapple(a fructogenic waste) and cassava (a glucogenic waste). It was also designed to allow a comparative analysis of pure ethanol with ethanol produced from the two food wastes with a view to generate an alternative fuel source. The parameters evaluated were the volume ofbioethanol per $100 \mathrm{~g}$ of waste, percentage (\%) purity of bioethanol produced, $\mathrm{pH}$ and auto ignition temperature of bioethanol produced. The values obtained were analyzed using the unpaired student's $t$ - test where appropriate to determine if there are any significant differences in pure ethanol values for those parameters. The result showed thatrelative to the pure ethanol(control), the auto ignition temperature of ethanol produced from the cassava (Manihot esculenta)and pineapple(Ananas comosus)wastes were significantly $(p \leq 0.05)$ high. The autoignition temperature of ethanol produced from pineapple waste was slightly higher when compared to bioethanol from cassava waste but it was not statistically significant $(p>0.05)$. The volume of ethanol produced from cassava waste was slightly lower $(p>0.05)$, when compared to the volume of the same parameter in the pineapple waste. There was a significant $(p \leq 0.05)$ decreasein $\mathrm{pH}$ of ethanolproduced from pineapple waste when compared to that from cassava waste. The $\%$ purity of the bioethanol produced from pineapple waste was higher $(p>0.05)$ when compared to that from the cassava waste. The autoignition temperature of the blend of produced bioethanol was slightly reduced $(p>0.05)$ when compared to the auto ignition temperatures of individual ethanol from separate waste. But, relative to the pure ethanol utilized as a control in this study, the autoignition temperature of the blend was significantly $(p \leq 0.05)$ high. Finally, it was observed that bioethanolobtained from cassava waste (a glucogenic energysource) produced a lower yield involume with a $15.8 \mathrm{v} / 100 \mathrm{~g}(\mathrm{ml})$ value while its fructogenic counterpart (pineapple waste) exhibited a slightly lower autoignition temperature effect $\left(33^{\circ} \mathrm{C}\right)$. The autoignition temperature of the waste blend (Cassava-Pine) was $30^{\circ} \mathrm{C}$ when compared to each waste source alone.A combination of both cassava and pineapple waste yielded better fuel properties and iscampaigned in this study for use in the production of biofuel.
\end{abstract}

Key words: Bioethanol production, pineapple waste, cassava waste, Warri.

\section{Introduction}

Fossil fuel is reported to have grave deleterious effects on the environment [1]. This is due to its propensity to increase the level of carbon (IV) oxide $\left(\mathrm{CO}_{2}\right)$, a greenhouse gas, directly responsible for global warming [2].Bioethanol produced from renewable sources is gaining global recognition due to the continuous depletion of fossil fuel [3]. Food products like corn and sugar cane containing fermentable sugars are utilized all over the world for the production of bio- fuel [4]. There are also reports suggesting that ethanol produced via fermentation accounts for approximately 95\% bioethanol production [3]. In Nigeria, tons of foods and fruits wastes are generated allyear round owing to poor storage facilities. This study was therefore designed tocomparatively evaluate bioethanol 
production from pineapple (Ananas comosus) and cassava (Manihot esculenta) waste within Warri and environs with a view to finding out the suitabilityof theuse of thesewastes as raw materials for alternative fuel sources to fossil fuels.

\section{Materials and methods}

\section{Yeast and treatment of yeast source}

The treatment of yeast in this study was done according to the method described by [5]. Three gram (3g) of STK Royal Instant Dry Yeast, a product of STK Industry Limited Lagos, containing (S. cerevisiae) was dissolved in $1000 \mathrm{ml}$ deionized water; the mixture was heated in a water bath to $40^{\circ} \mathrm{C}$ to allow for complete dissolution.

\section{Saccharification of Cassava Waste}

Cassava waste was collected rinsed, blended and converted to sugar according to the method described by [6, 7] with a slight modification as described. Cassava blend $(20 \mathrm{~g})$ was pretreated with $10 \mathrm{ml}$ of $2 \% \mathrm{w} / \mathrm{w}$ tetraoxosulphate (VI) acid. The mixture was then treated with an enzyme mixture preparation (containing $\alpha$-amylase) and allowed to stand for $6 \mathrm{hrs}$. The filtrate was then inoculated with the yeast strain $(S$. cerevisiae)

\section{Fermentation of Cassava and Pineapple (Ananas comosu) extract}

The method used in the production of bioethanol in the study was thefermentation method described by [8, 9]using the commercially available yeast, Sacchromyces cerevisiae NCYC 2826 strain. $100 \mathrm{~g}$ of pineapple and cassava wastes obtained from Hausa Quarters, Igbudu Market Warri were packed in separate dark polyethylene bucket with a lid and allowed to stand for 10d. The wastes were then blended using a MX151SP2 Panasonic blender. The blend was filtered using a Whatman 20 Cellulose Filter paper. The filtrate was transferred into a black polyethylene container, and $3 \mathrm{ml}$ of the yeast solution was introduced into the container and the $\mathrm{pH}$ was adjusted to 5.8 using $5 \mathrm{M} \mathrm{NaOH}$ and $1 \mathrm{M} \mathrm{HCl}$ for upward and downward adjustment respectively. The black polyethylene bottle was put in an incubator at $30^{\circ} \mathrm{C}$ for $72 \mathrm{hrs}$.

\section{Purification of ethanol produced}

Ethanol produced was purified by table distillation method described by American Standard for Testing and Material (ASTMD86).

\section{Determination of Auto-ignition temperature}

This was done according to the ASTM E 659 method modified by [10]. Bioethanol sample was placed in a 500-millilitres flask placed in a temperature-controlled oven the initial temperature of ignition when exposed to a heat flame was recorded as the auto ignition temperature (ASTM E659).

\section{Statistical analysis}

All data obtained were analyzed using the student's ttest of the SPSS 16.0 statistical package and $p \leq 0.05$ was considered significant. The results were expressed as mean \pm SD.

\section{Results}

The result of the relationship between $\mathrm{pH}$ indices of bio-ethanol produced from cassava and pineapple are expressed in Figure 1.0. The $\mathrm{pH}$ value of cassava (Manihot esculenta) waste in this study was slightly $(\mathrm{P}>0.05)$ higher when compared to the $\mathrm{pH}$ of pineapple. The $\mathrm{pH}$ value of the bioethanol of the blend was enhanced when compared with the $\mathrm{pH}$ of bioethanol from cassava or pineapple alone. The $\mathrm{pH}$ value of the blend (Cassava-pine) was low when compared with the $\mathrm{pH}$ of the standard ethanol. 


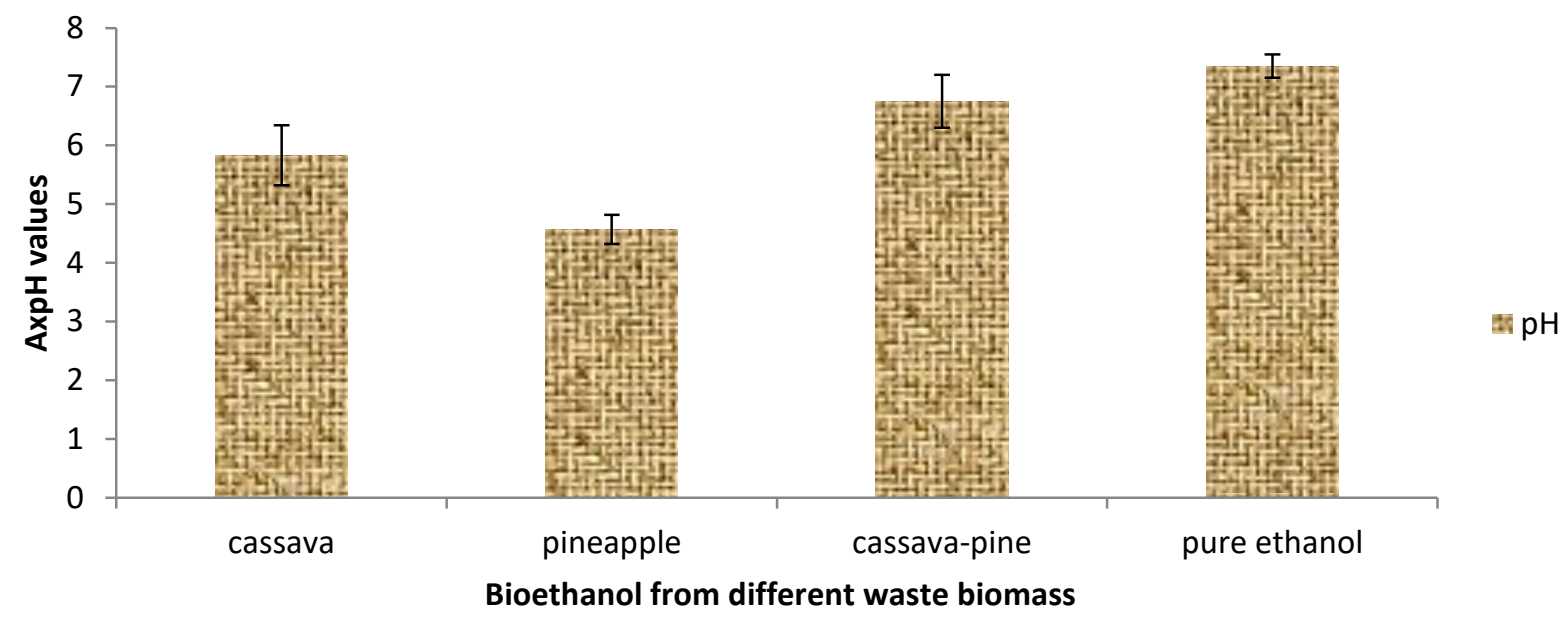

Figure1.0: pH of bioethanol from different waste biomass.

The result of the relationship between volume of ethanol produced from cassava and pineapple are expressed in Figure 2.0. The volume of bioethanol from cassava (Manihot esculenta) waste in this study was lower $(p>0.05)$ when compared to the volume of ethanol from pineapple waste and also when compared with the volume of bioethanol produced from the blend of cassava and pineapple.

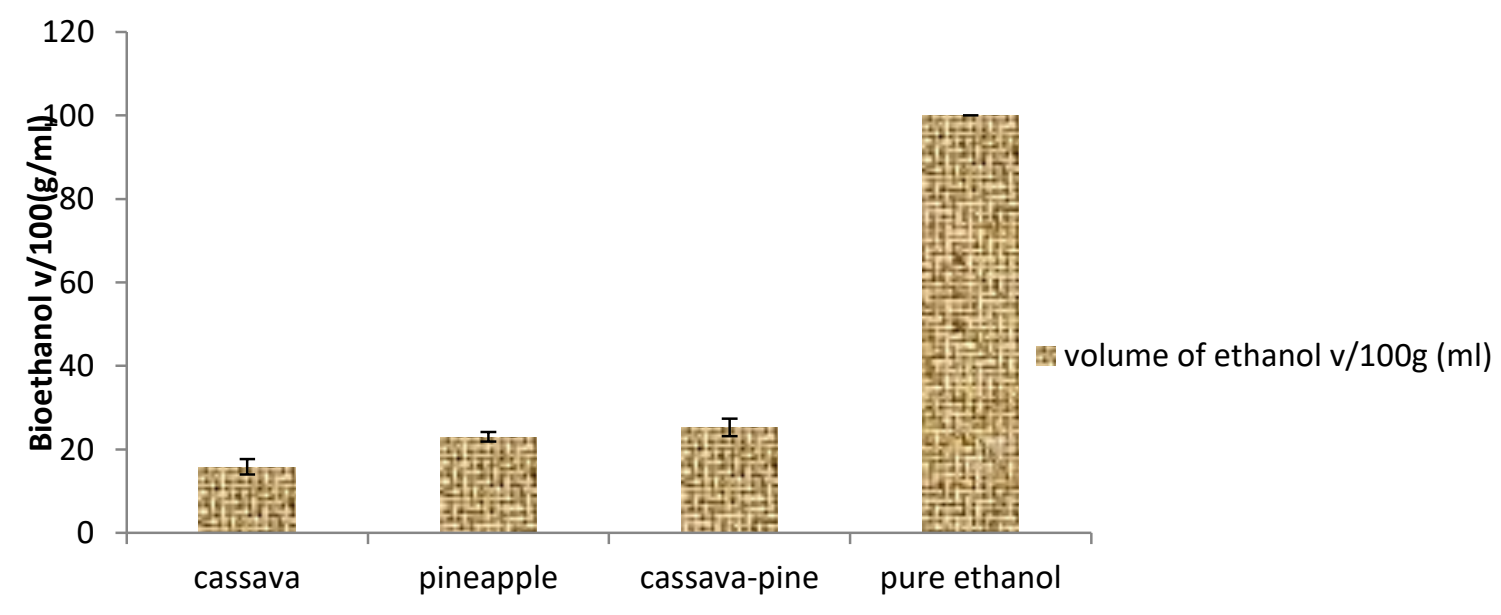

Ethanol from cassava and pineapple biomass in Warri

Figure 2.0: Bioethanol from waste biomass in Warri.

The result of the percentage purity of bioethanol produced from cassava and pineapple waste biomass from Warri are expressed in Figure 3.0. The \% purity of bioethanol from cassava (Manihot esculenta) waste in this study was the lowest (62\%) when compared to the values obtained for pineapple, cassava-pine and pure ethanol with values of $76 \%, 80.10 \%$ and $98 \%$ respectively. 


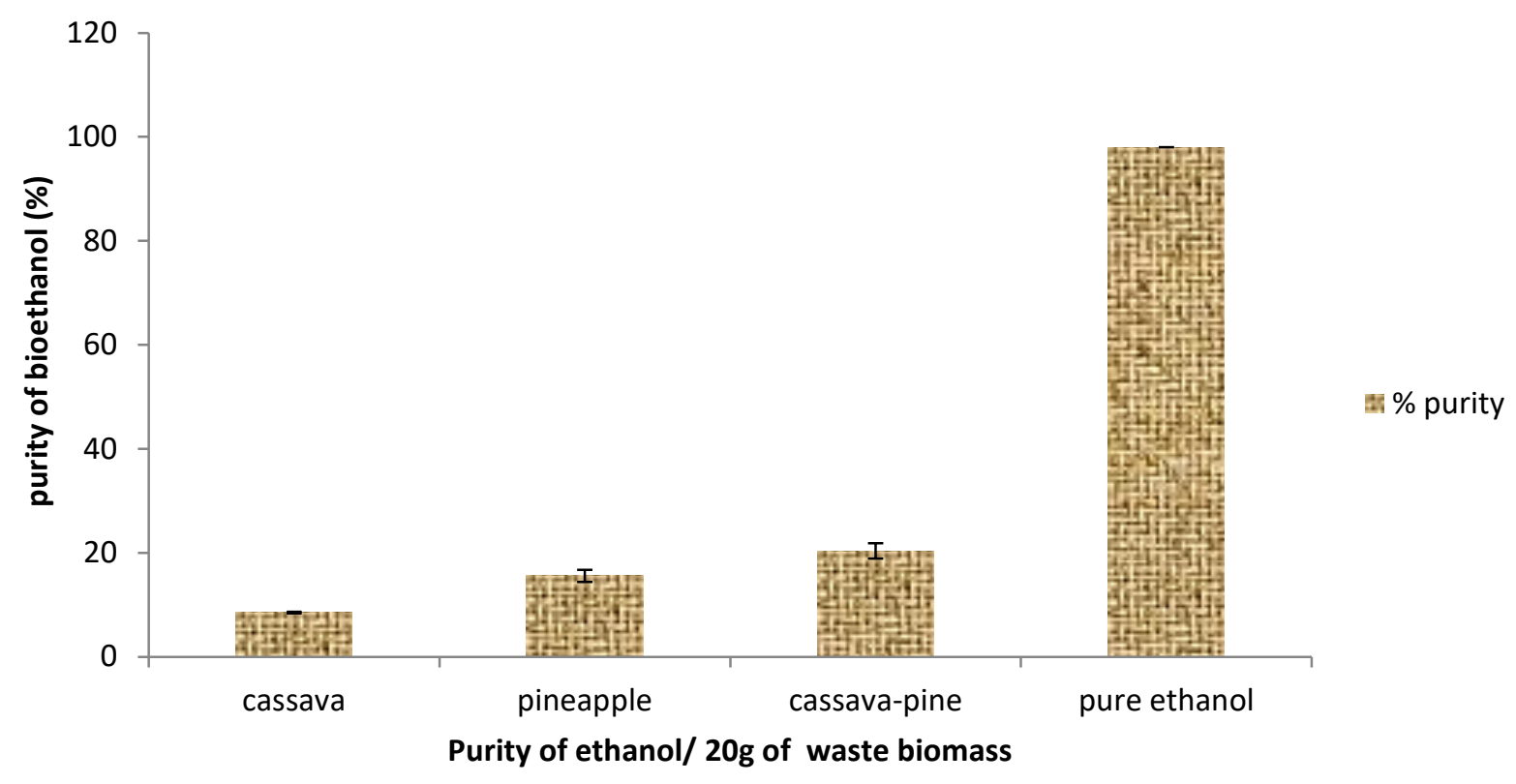

Figure 3.0: Percentage purity of bioethanol from different biomass in Warri.

The autoignition temperatures of bioethanol from cassava and pineapple waste are expressed in Figure 4.0. The auto-ignition temperature of bioethanol produced from cassava was slightly high $(\mathrm{P}>0.05)$ when compared to the auto-ignition temperature of pineapple waste and the blend (cassavapine). The auto-ignition temperature of cassava, pineapple and cassava-pine were significantly $(\mathrm{P}<0.05)$ high relative to the $13^{\circ} \mathrm{C}$ auto-ignition temperature of pure ethanol evaluated in this study.

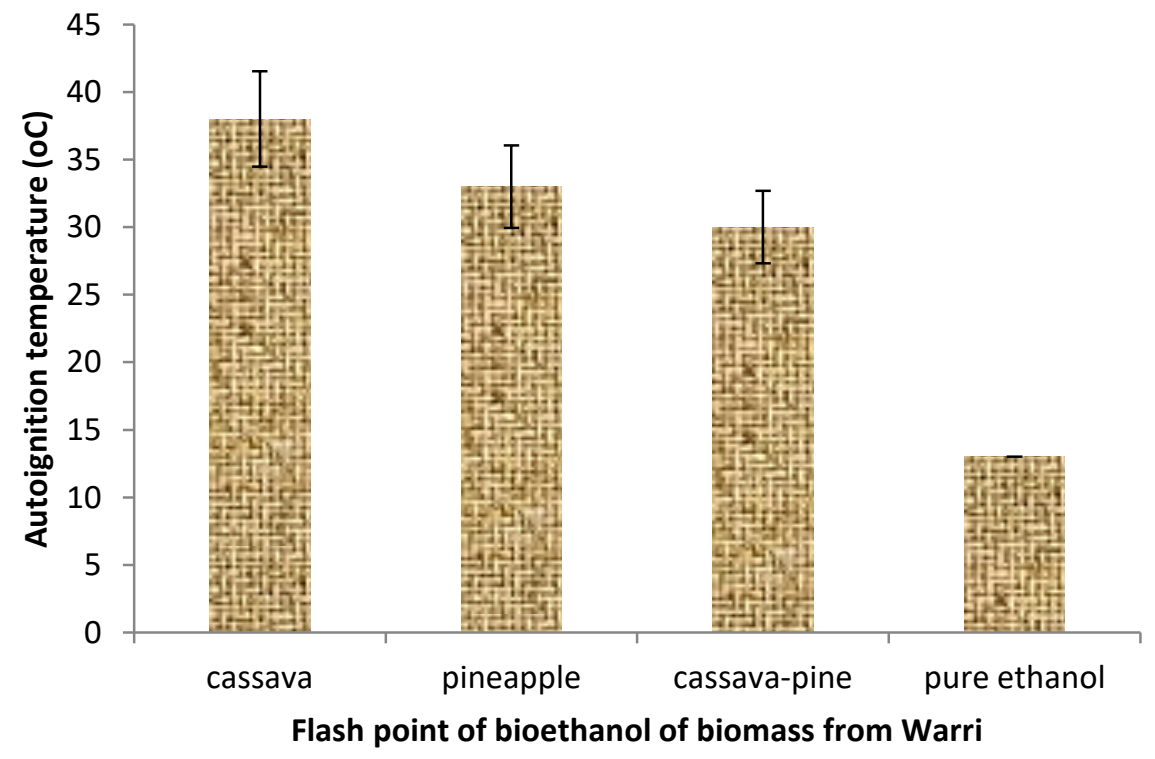

Autoignition temperature

Figure 4.0: Auto-ignition temperature of bioethanol of biomass mass from Warri 


\section{Results and Discussion}

The main purpose of this study was to evaluate ethanol production from glucogenic and fructogenic waste sources with a view to ascertaintheir suitabilityfor use inbiofuel production.

Studies showed that sucrose-containing materials simplify the ethanol production process, which could eventually lead to high yield [11]. Our result revealed a slight elevation in bioethanol from pineapple waste biomass when compared to its cassava counterpart. This study gives credence to the report of [12] but does not agree with the report of [13] who demonstrated that a glucogenic biofuel source produced a higher volume of bioethanol due to the high photosynthetic efficiency. In this study, the observed increase volume of bioethanol from cassava-pine blend may be due to high biomass of the cassava.

Autoignition temperatures are useful indicators of suitability of the material for

\section{REFERENCES}

1. S.Prasad, A., Singh and H.C Joshi. (2007). Ethanol production from sweet sorghium syrup for utilization as automotive fuel in India, Energy and Fuels, 21(4): 2415-2420

2. S.N Naik, V.V Goud, P.K Rout and A.K Dalai. (2010). Production of first and second generation biofuels: A comprehensive review.Renewable and Sustainable Energy Reviews 14(2):578-597.

3. Z. Hossain F. Golam J.N Sahu, M. S, Azirun and A. N, Boylce. (2014). Bioethanol production from fermentable sugar juice. The Scientific World Journalhttps://doi.org/10.1155/2014/ 957102

4. J., Goldenberg, S. T., Coelgo, and P. Guardabassi. (2008). The sustainability of ethanol next term fuel. Substances with autoignition temperatures near and below ambient temperature have been proven to be excellent fuel sources. Low auto ignition temperature is associated with increased volatility of fuel [10]. In our present study, the autoignition temperature of bioethanol from pineapple was lower than that from cassava. This could be because the bioethanol from the fructogenic food source (pineapple) is slightly volatile than that from the glucogenic food source (cassava).

\section{Conclusion}

The waste biomass of cassava and pineapple may serve as a potential source of raw material for alternative energy by the presence of some indicators of a good fuel. This study therefore provides some scientific support for the utilization of food waste as an alternative fuel source However, it is necessary to carry out some more comprehensive study of all the parameters use as indicators of a good fuel that were not captured in this study.

production from previous term sugarcane. Energy Policy. 36(6): 2086-2097.

5. A.B.M.S, Hossain. and A.R. Fazliny, (2010). Bioethanol production from pineapple waste and the usage of its properties for engine. African Journal of Microbiology Research, 4(9):813-819.

6. R., C. Leng, C., Wang, Zhang, D. Dai, and G. Pu. (2008). Life cycle inventory and energy analysis of cassava-based Fuel ethanol in China. Journal of Cleaner Production. 16: 374-378.

7. J. Berlowska, K. Pielech-Przybylska, Balcerek, M., Cieciura, W., Sebastian Borowski, and D. Kregiel. (2017). "Integrated bioethanol fermentation/anaerobic digestion for valorization of sugar beet pulp," Energies, 10(9): 1255 
8. S.H.M, Azhar, M., Abdulla, S.A.,Jambo, H. Marbawi, J. A. Gansau, A.A.M, Faik, K. F. Rodrigues, K. F.(2017). Yeasts in sustainable bioethanol production:A review. Biochemistry and Biophysics Reports, (10): 52-61.

9. J.A. Quintero, M. I., Montoya, O. J. Sanchez, O. H. Giraldo, and C. A. Cardona. (2008). Fuel ethanol production from sugarcane and corn: Comparative analysis for Colombian case. Process Biochemistry. 34: 115119.

10. K. C. Smyth and N. P. Bryner. (1991). Short duration autoignition measurement for hydrocarbon fuels. National Institute for Standard and Technology (NIST) Gaitherburg MD.

11. E659 - 78 (Reapproved 2000), "Standard Test Method for Autoignition Temperature of Liquid
Chemicals", ASTM, 100 Barr Harbor Drive, West Conshohocken, PA 19428-2959.

12. M.C. Gallignani, M. Ayala, M. Del Rosario,J.Brunetto, L. Burguera, and M. Burguera. (2005). A simple strategy for determining ethanol in all types of alcoholic beverages based on its on-line liquid-liquid extraction with chloroform, using a flow injection system and Fourier transform infrared spectrometric detection in the mid-IR. Talanta. 68(2): 470-477

13. F.C.F. Giorgis, P. Tresso, A.M. Rava, G. R. Paterson, D.A Doqling, E. Chamberlain, D.P. Billa,Koullas, B. Monties and E. G. Koukios. (1997). Structure and composition of sweet sorghum stalk components. Industrial Crops and Products. 6: 297-302. 